\title{
Deficiencies in China's innovation systems for coal-bed methane development: comparison with the USA
}

\author{
Philip Andrews-Speed \\ Energy Studies Institute, National University of Singapore, \\ Singapore, Singapore \\ Xiangyang Xu and Dingfei Jie \\ School of Management, \\ China University of Mining and Technology - Beijing Campus, Beijing, China

\section{Siyuan Chen \\ School of Management and Economics, Beiiing Institute of Technology, Beijing, China, and \\ Mohammad Usman Zia \\ Sinclair Kennedy Fellow (2021-2022), Harvard University, Cambridge, Massachusetts, USA}

\begin{abstract}
Purpose - This paper aims to identify the factors that are constraining technological innovation to support the development of coalbed methane in China.

Design/methodology/approach - The analysis applies ideas relating to national and sector systems of innovation to explain why China's strategies to support research and technological innovation have failed to stimulate the desired progress in coalbed methane production. It also provides a counter-example of the USA that implemented a number of measures in the 1970s that proved very effective.

Findings - The deficiencies of China's research and development strategies in support of coalbed methane development reflect the national and sectoral systems of innovation. They are exacerbated by the structure of the national oil and gas industry. Key constraints include the excessively top-down management of the national R\&D agenda, insufficient support for basic research, limited collaboration networks between companies, research institutes and universities and weak mechanisms for diffusion of knowledge. The success of the USA was based on entirely different systems for innovation and in quite a different industrial setting.
\end{abstract}

(c) Philip Andrews-Speed, Xiangyang Xu, Dingfei Jie, Siyuan Chen and Mohammad Usman Zia. Published by Emerald Publishing Limited. This article is published under the Creative Commons Attribution (CC BY 4.0) licence. Anyone may reproduce, distribute, translate and create derivative works of this article (for both commercial and non-commercial purposes), subject to full attribution to the original publication and authors. The full terms of this licence maybe seen at http:// creativecommons.org/licences/by/4.0/legalcode

The project received funding from the Shanxi Province Joint Research Fund of Coalbed Methane (Grant no. 2015012017). 
JSTPM 14,3

Originality/value - The originality of this analysis lies in placing the challenges facing research and innovation for China's coalbed methane development in the context of the national and sectoral systems for innovation and comparing with the approach and success of the USA.

Keywords China, USA, Innovation, Research, Coalbed methane

Paper type Research paper

\section{2}

\section{Introduction}

Efforts to exploit coal-bed methane (CBM) in China date back to the 1980s. The initial motivation was the need to produce more energy to support economic growth. An additional driver in recent years has been the policy of substituting gas for coal to reduce air pollution. However, production of CBM has risen only slowly and has consistently fallen below formal targets despite substantial government support. This failure is particularly striking when China's CBM production profile is contrasted with that of the USA (Figure 1), despite China and the US Lower 49 States ranking second and third in the world in terms of estimated CBM resource (Masterlerz and Drobniak, 2020). There are many reasons for this, including the inadequate nature of economic incentives, conflicts over resource rights and paucity of pipelines. Steps have been taken recently to address these particular constraints.

More fundamental is the greater geological complexity and specific characteristics of Chinese gas-bearing coal seams compared to those in the USA. In response, China's Government and companies have been increasing their spending on scientific and technological research and development (R\&D) relating to CBM. However, these efforts and expenditures appear to have yielded only modest benefits in terms of increasing production. While many accounts have identified the need to devote more attention to R\&D for CBM, few have examined the context in which this R\&D takes place. This is of interest not just due to the need to boost domestic gas

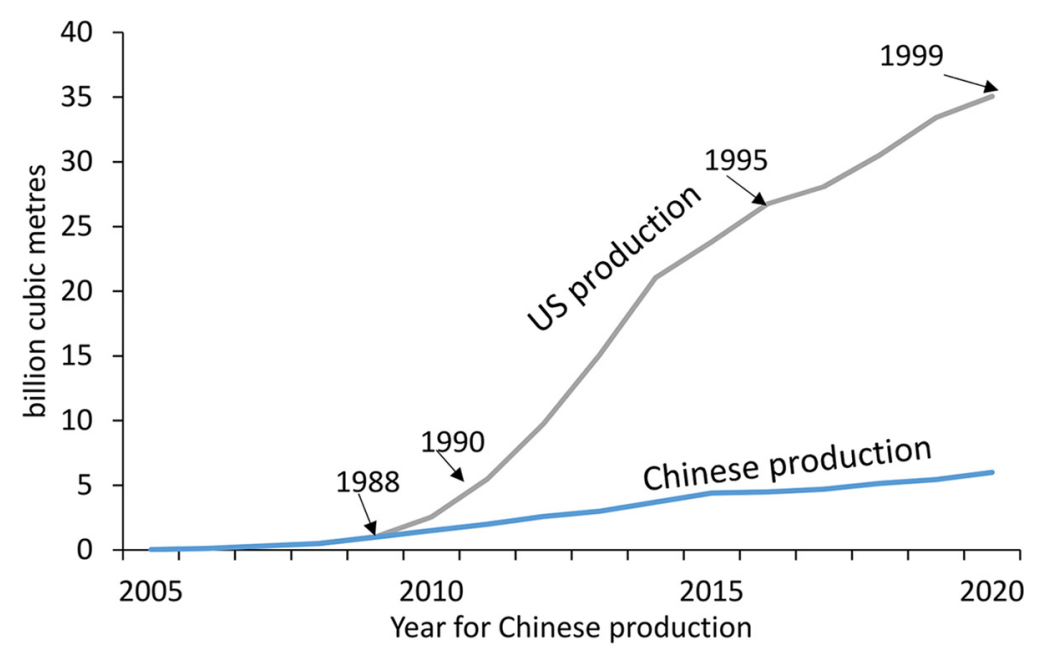

Figure 1.

Annual production of CBM in China and USA
Note: The US data runs from first production in 1983 to 1997 , with a data gap between 1984 and 1988. The Chinese data is according to the horizontal axis. Sources: China (various); USA (US Energy Information Administration, undated a; Murray, 1996) 
production but also because China's Government places a high priority on technological innovation, with a degree of success in some sectors (Kennedy, 2020). This raises the question of why similar innovation success is not being met in the case of CBM and in the same way that the USA was able to innovate to boost CBM production in the 1980s and 1990s.

This paper aims to identify the factors that are constraining technological innovation to support CBM development in China. The analysis will be based on concepts from the innovation systems literature, focusing on the national system for innovation, the nature of the nation's oil and gas sector, and the sectoral system for innovation as it applies to CBM. The experience of the CBM industry in the USA is presented as a counter example to highlight factors that may be constraining innovation in China. Like China, the USA has a large estimated CBM resource (Masterlerz and Drobniak, 2020), but achieved much greater success in raising production since the 1980s. Its systems for innovation are quite different from those in China, as is the structure of its oil and gas industry. The hypothesis of the paper is that these have been important, though not the sole factors in determining the contrasting production trajectories of the two countries.

The research is based on the analysis of relevant the academic literature and of official publications and data, and a limited number of interviews in Beijing. There have been a several data limitations. Detailed information on the operations and finances of the US Gas Research Institute for the period under consideration (1976-2000) is not available, and we have had to rely on a small number of reports, two of them obtained directly from somebody who had worked at the Institute. Likewise, data on how many companies were involved in CBM development during this period was not available. In China, the most significant challenge has been to find systematic information on the research funding for R\&D.

The paper begins with a summary of the challenges facing China as it seeks to exploit its coalbed methane resources in Section 2, focusing on the technological obstacles. Section 3 outlines the main features of innovation systems that will be applied in this analysis, highlighting the role of networks and coordination and the nature of the relevant industrial sector. Sections 4 and 5 examine, in turn, the USA and China, revealing striking contrasts between their national systems for innovation, the nature of their oil and gas industries and their sectoral systems for innovation as they relate to CBM. Of particular importance is the relatively weak coordination in China's innovation systems and the low level of diversity in the country's oil and gas industry. We argue that these differences may be among the factors that have inhibited the required technological innovation needed to support growing CBM production in China.

\section{China's coalbed methane challenge}

Before the 1980s, the extraction of methane from coal seams in China was solely for safety in coal mines (Tao et al., 2019a). The government launched the first modest policies to support the development of CBM in the 1980s, but only identified CBM as a critical industry in 1989 (Sun and Huang, 1996). The 1990s saw China take significant initiatives in response to the success of the USA. The Ministry of Coal Industries included CBM in its plan for 1994-2000 and the government established the China United Coal Bed Methane Corporation (CUCBM) in 1996. Other Chinese companies started to take an interest in CBM and foreign companies, large and small, arrived to assess the scale of the resource (Regan and Zhu, 2014; Tao et al., 2019a). The Tenth Five-Year Plan for Energy 2001-2005 identified CBM R\&D as a key priority. The number of pilot projects grew, 12 production sharing contracts (PSCs) were signed with foreign companies and methane production rates from test wells started to rise as understanding of the geology improved (Regan and Zhu, 2014).

It was only from 2006 that the government started to promulgate multiple policies to support CBM development including, for the first time, a Five-Year Plan for CBM. This 
JSTPM 14,3

included a target for production of 5 billion cubic metres (bcm) by 2010 (Xu, 2021). Key fiscal measures included a subsidy of 0.20 RMB per cubic metre of produced CBM, a waiver of resource tax (royalty) and preferential VAT and income tax treatment for CBM extraction enterprises. Shanxi Province, the location of most CBM activity, provided an additional 0.05 RMB per cubic metre subsidy. Moreover, the government provided a 150\% tax deduction for all science and technology R\&D costs as part of the Medium- and Long-Term Plan for Science and Technology 2006-2020. These policies resulted in the first commercial production, with annual output reaching $1 \mathrm{bcm}$ in 2009. The output was mainly from the Qinshui Basin in Shanxi Province and from Liaoning Province. Despite the failure to meet to 2010 target of $5 \mathrm{bcm}$ annual production, the government set a target for 2015 of $16 \mathrm{bcm}$ and PetroChina aspiring to produce $20 \mathrm{bcm}$ annually by 2020 (Regan and Zhu, 2014).

The desire to boost the domestic supply of gas to substitute for coal and the reinvigoration of China's ambitions to be a great hub of science and technology led to further support measures being introduced between 2013 and 2019. These included increasing the subsidy for CBM to $0.30 \mathrm{RMB}$ per cubic metre, raising the tax deduction for all R\&D to $175 \%$, and issuing a Coalbed Methane Action Plan in 2015. Shanxi Province increased their supplementary subsidy to $0.1 \mathrm{RMB}$ per cubic metre. Nevertheless, CBM production has continued to rise only gradually, reaching just $6.0 \mathrm{bcm}$ in 2020 (Figure 1). This was far short of the $10 \mathrm{bcm}$ target set by the 13th Five-Year Plan for Coal Bed Methane in 2016.

Numerous above-ground and non-technological factors have been acting to constrain CBM production. These include: the limited number of Chinese companies involved; poor framework for foreign investors; the conflict between CBM producers and coal miners over resource rights; the low level of the subsidy for CBM production in comparison to costs; and the shortage of pipelines and absence of third-party access to these pipelines (Regan and Chu, 2014; Tao et al, 2019a).

In response, the central government has been addressing the issue of resource rights (State Council, 2017). It has also issued regulations on third-party access to oil and gas pipelines and created a new national pipeline company (Andrews-Speed and Yao, 2019). To increase the number of actors involved in CBM it has delegated the licensing of resources rights to provincial governments and has removed the need for foreign companies to enter into a PSC with a Chinese enterprise (Jin et al., 2019). In addition, the Government of Shanxi Province has tightened its management of resource rights for new CBM blocks by requiring relinquishment if the level of expenditure and activity falls below a certain level (Liu and Sun, 2019). However, the subsidy remains at $0.30 \mathrm{RMB}$ per cubic metre of CBM produced.

Notwithstanding these actions, a key factor constraining the rise of production continues to be the geological conditions of the CBM resource (Li et al., 2018; Tao et al., 2019b). As a result, gas flow rates are much lower than in the USA, well bores collapse easily causing drilling equipment to stick, hydraulic fracturing is more challenging and coal beds are less continuous. Operators in China have been trying different designs for clusters of horizontal wells and deploying various techniques for fracturing and artificial lift. These more advanced methods have led to improvements. Still, average single well production rates have remained significantly below those in Australia and the USA, in part because the most advanced techniques are not widely deployed on account of their high cost.

This relative lack of success cannot easily be attributed to a shortage of public funding. The number of formal government documents recognising the need for $R \& D$ to support CBM development increased steadily since 2006. In parallel, the scale of funding of this R\&D has grown. Whilst it has not been possible for us to document all such public R\&D funding systematically, secondary sources suggest that billions of RMB were provided by the government between 2006 and 2015 alone (Tao et al., 2019a). This raises the question of 
what elements in China's national and sectoral systems of innovation are constraining the development of the technologies required to boost the production of CBM.

\section{Innovation systems}

There are many definitions of an innovation system, but two are particularly useful for this analysis:

(1) "A system of innovation is constituted by the elements and relationships which interact in the production, diffusion and use of new, and economically useful knowledge." (Lundvall, 1992).

(2) "set of institutions whose interactions determine the innovative performance [...] of firms". (Nelson, 1992).

The key element in these and other definitions is interaction. The overall function of an innovation system is the support of learning that leads to innovation. However, learning and innovation require interactions between these actors, for example through networks of knowledge and competence (Edquist, 2001; Lundvall, 2007). Such a system for the production and diffusion of knowledge was termed "knowledge infrastructure" by Smith (1997). Networks form a central component of knowledge infrastructure. Of these, knowledge networks are especially important, not that supply chain networks are irrelevant to the innovation process (Gesling, 1992). These knowledge networks bring together actors with different skills, objectives and operating contexts, ranging from entrepreneurs, large integrated corporations, research institutes and universities (Carlsson and Stankiewicz, 1991; Smith, 1997).

Intermediary organisations such as public research institutes and industry associations can also enhance coordination, interaction and knowledge diffusion through the creation of new networks (Intarakumnerd and Goto, 2018). Further, the state may have an important role filling gaps in the innovation system to accelerate innovation. In addition to providing strategic direction for innovation and funding for $R \& D$, the state may need to create actors, networks, system links or institutions to enhance the effectiveness of learning and innovation (Edquist, 2001).

Given this understanding of innovation systems, it is self-evident that the structures, functions and effectiveness of national systems of innovation (NSIs) will vary between countries and cultures, as they depend on a wide range of formal and informal institutions (Nelson and Rosenberg, 1993). Such factors include the education, legal, political, economic and financial systems, the structures and systems of government, the nature of property rights including intellectual property rights (IPR), the ownership and structure of industry and the skills, organisation and mobility of the labour force (Carlsson and Stankiewicz, 1991; Nelson, 1992).

These same principles shape the effectiveness of sectoral systems of innovation (SSIs). Different economic sectors in a country will possess distinct characteristics with respect to numbers and heterogeneity of actors, barriers to entry and exit, level of entrepreneurialism, nature and maturity of technologies and nature of the market and level of competition. Of particular importance are the formal and informal networks between firms (Malerba, 2002). For these reasons, countries may not necessarily be able to replicate the innovation success of another country in a particular sector (Malerba, 2006).

Given the importance at both national and sectoral scales of meaningful interactions between actors to produce and disseminate useful innovations, one of government's roles is to "build bridges across disciplines and between upstream and downstream", if necessary through the construction or enhancement of networks (Popper and Wagner, 2002). In their comparison of the national systems for innovation in China and the USA, Melaas and Zhang 
JSTPM 14,3
(2016) concluded that the level of coordination and integration was higher in the US than in China despite the greater decentralisation and diversity of actors in the former.

For these reasons, in comparing the national and sectoral systems of innovation in China and the USA, this paper will focus principally on the coordination of innovation and the development of R\&D networks. The nature and heterogeneity of the national oil and gas sectors and the barriers to entry are also important as they help shape the sectoral system of innovation.

\section{The US national system of innovation and its application to coal-bed methane}

4.1 The US national system of innovation

The US NSI dates back to the early years of the twentieth century when private industrial enterprises, notably chemicals companies, started to realise the value of scientific research to innovation and established their own laboratories. In the years leading up to World War Two, universities built up their research capabilities and developed links with industry. The structures developed for military R\&D during World War Two formed the basis for the subsequent structures and systems (Mowery and Rosenberg, 1993).

The period since 1953 has seen a sustained increase in total funding for R\&D in the USA, with an acceleration after the mid-1970s. Federal expenditure on R\&D climbed steeply during the late 1970s and 1980s, the period under consideration in this paper. Since the 1980s, industrial funding for R\&D has risen more rapidly than that from the federal government. Further, the share of R\&D funding deployed by industry has consistently outweighed that of the federal government and universities. Certain states, such as Michigan, Massachusetts and California, also have a strong track record of funding research (Simons and Walls, 2010).

A vital attribute of the US NSI is the dominant role of private actors and their diversity, as is the case in the oil and gas industry (see Section 4.2). Although federal laboratories play an essential role, private enterprise carries out and funds most $R \& D$. These firms have rapid reaction times and can absorb new technologies rapidly (Popper and Wagner, 2002). Further, venture capital has played an increasingly important role since the 1990s (Simons and Walls, 2010). Despite their dominance of $R \& D$, industrial firms began to increase their collaboration with universities and federal laboratories in the 1980s due to competitive pressures, as well as forming other types of research alliances (Mowery, 1998). These practices were then carried over into innovation for CBM development, as will be explained in Section 4.3.

The high level of industrial innovation achieved by the USA in recent decades has been attributed to several underlying conditions in addition to the levels of funding and the role of private enterprise. These include the protection of intellectual property rights, tax incentives, a diverse range of enterprises, the low barriers to entry and exit for both business and technology, a mix of basic and applied research, a strong tertiary education system and active capital markets (Popper and Wagner, 2002; Simons and Walls, 2010). In addition, the federal government has played an important role, where needed, as a convener and builder of networks (Popper and Wagner, 2002), as will be illustrated in the case of gas research in Section 4.3.

\subsection{Key features of the US oil and gas industry}

The US oil and gas industry possesses two features that distinguish it from those of other countries. Both relate to private ownership. First, and uniquely today, the rights to subsurface resources in the USA lie with the individual landowner, except in the case of 
State and Federal lands. As a result, the landowner has the incentive to encourage the exploitation of any resources below their land to benefit from the required royalty payments. This system also helps to prevent any one company being able to monopolize production rights to a resource.

The second feature is the large number and diversity of companies involved in the US oil and gas industry. From its origins in 1859, the US oil and gas industry has been populated by private actors, large and small, with no state-owned enterprises. After the break-up of the Standard Oil Company of New Jersey in 1911, no single company has dominated the domestic industry. By the 1950s, the number of companies involved along the US oil and gas supply chain was estimated to be about 30,000 (British Petroleum, 1958). Between 1955 and 1970, the largest 20 US integrated oil and gas companies increased their share of domestic oil production from 46 to $68 \%$.

In the 1970s, the extent of joint ventures in upstream projects had raised concerns over competition and price-fixing (Flaim, 1979). However, the dominance of the top eight companies over natural gas reserves and production in 1976 (39 and 36\%, respectively) was less than for crude oil reserves and production (57 and 40\%, respectively; Jones et al., 1978). Today, the American Petroleum Institute claims more than 600 members along the entire length of the supply chain [1]. According to the Independent Petroleum Association of America, there are about 9,000 independent oil and gas producers in the USA. In their definition, an independent company has no more than US $\$ 5 \mathrm{~m}$ per year of sales or a refining output of no more than 75,000 barrels per day [2].

A study by IHS Markit (Fryklund et al., 2019) identified 128 oil and gas independent companies, distinct from eight global companies, as well as 2,079 small private companies. This report also showed that the independent companies, large and small, had played a pivotal role in developing the country's unconventional oil and gas reserves in the second decade of the twenty-first century. We have not been able to find information on how many companies were involved in developing the US's CBM resource in the 1980s and 1990s as production grew. However, data at the time of peak CBM production in 2008 reveals that the most productive basins each hosted tens of companies, for example: 68 in the Powder River basin, 55 in the San Juan Basin, 41 in the Arkoma Basin, 36 in the Cherokee/Forest City Basin and 32 in the Anadarko Basin (US Environmental Protection Agency, 2010). Although, many companies will have operated in multiple basins, these numbers reflect low barriers to entry and a relatively high degree of competition.

\subsection{The US sectoral system for innovation as it relates to CBM}

Such a high degree of competition and diversity in the oil and gas industry might have undermined collaborative research. However, the US Government took active steps to build on the practice of cooperation that was growing in the NSI by creating an organisation with the primary role of ensuring that relevant actors in the SSI cooperated in their research efforts. This was part of a wider effort to support and coordinate R\&D for gas production, including CBM, in the late 1970s and 1980s.

The oil crises of the 1970s triggered a rapid response by the US Government to boost the domestic production of different forms of energy, including natural gas. The main measures taken were:

- The 1978 Natural Gas Policy Act;

- Section 29 of the 1980 tax credit on energy;

- Funding from the US Department of Energy (DoE);

- Field and laboratory research by the US Geological Survey (USGS); and 
JSTPM 14,3
- The establishment of the Gas Research Institute, later reorganised to become the Gas Technology Institute.

The Natural Gas Policy Act aimed to create a national market for natural gas. It gave the newly created Federal Energy Regulatory Commission (FERC) authority over intra-state and inter-state gas markets (US Energy Information Administration, undated b). The 1980 tax credit gave a significant additional incentive for unconventional natural gas producers, much more than any tax deduction could have given (Soot, 1991). Between 1978 and 1982, the DoE provided US\$29 million to the Methane Recovery from Coalbed Program (MCRP), a project to define the size and recoverability of domestic coalbed methane (Anonymous, 2021). It has been estimated that the US $\$ 29$ million of DoE funding yielded economic benefits amounting to US\$200 million (1991 dollars) (National Academic of Sciences of the US, 2001). The USGS followed up the work of the MCRP assessing the resource. This work has continued to the present day, and the results are publicly available (US Geological Survey, 2021).

At the heart of this wide-ranging initiative lay the Gas Research Institute (GRI), an organisation created explicitly to build networks between companies, research institutes and universities. This organisation was established in 1976 as an independent agency that justified its research budget to FERC, its financer. In 2000, it merged with the Institute of Gas Technology, a technical training institution, to form the Gas Technology Institute (GTI) that continues to operate today.

The mission of the GRI was to select the most cost-effective technologies to support the production, transportation and use of natural gas to the benefit of all stakeholders along the supply chain. Its primary function was to decide which projects to fund, who to fund and how much to invest. All of its research was contracted out and it did not possess any of its own laboratories. In this way, the GRI was a project management agency. Its total staff numbers reached 271 by 1987, of whom 179 were directly involved in managing research projects (Gas Research Institute, 1987).

The funding for the institute came from surcharges on the shipment of gas via interstate pipelines. R\&D expenditure rose from US\$20 million in 1979 to US $\$ 118$ million in 1986 (Gas Research Institute, 1987). By the 1990s, the annual budget was around US\$200 million. The GRI would submit to FERC a research and development strategy every five years and would request a certain percentage of funds from the inter-state pipeline tariff revenue that the FERC received (Burnett et al., 1993). Whilst some projects were funded solely by the institute, those that were moving beyond the proof-of-concept stage were required to involve the participation of and funding from one or more industry partners. Between 1980 and 1986, the annual income from industry for such projects rose from US $\$ 15$ million to US $\$ 57$ million. The number of funders reached 272 by 1986, of which 56 were gas-producing companies and nine were oilfield service companies (Gas Research Institute, 1987). This approach ensured the commitment of these firms to the collaborative effort.

In its strategic approach, the GRI was careful to seek an appropriate balance between long-term R\&D, including basic research, and near-term R\&D. Although, its top priority was R\&D related to the end use of gas, it devoted about $38 \%$ of its funds to $R \& D$ at the production end of the supply chain during the period 1978-1986. It applied a rigorous, quantitative project appraisal methodology to choose R\&D projects that aligned with its goals. A key requirement was to terminate projects that were unlikely to yield significant economic benefits. This minimised wasteful funding.

In the 1980s, GRI had four board-level advisory bodies to guide programme design and budgeting and also received technical support for specific projects from 15 project advisory groups (Burnett et al, 1993). By 2001, the Natural Gas Supply Project Advisor Group of the 
renamed Gas Technology Institute consisted of 32 exploration and production companies. Contract research relating to coalbed methane had involved about 70 organisations, including exploration and production companies, oilfield service companies, universities, consultancies, research organisations, industry associations and state geological surveys (Perry, 2001). This was an extensive collaborative effort.

Technological advances of relevance to CBM were quick to come. By 1986, these included fracture placement, fracture azimuth measurement, integrated log analysis systems, portable realtime monitoring systems, and two-dimensional seismic borehole tomography (Gas Research Institute, 1987). Between 1978 and 1993, Gas Research Institute completed and commercialised 30 gas technologies with calculated benefits of US $\$ 2$ billion in net present value. Over the same period, it achieved a project success rate of $30 \%$ and a benefit to cost ratio of seven to one. Moreover, the institute's research lead to the discovery of between $700 \mathrm{bcm}$ and $2,500 \mathrm{bcm}$ of additional gas resources by 1989 (Burnett et al., 1993). This resulted in annual CBM production rising from $1.0 \mathrm{bcm}$ in 1988 to $35.1 \mathrm{bcm}$ in 1999, a period of just 12 years (Figure 1).

Most of the research yielded outcomes that were not amenable to patent protection or licensing. In those cases where patentable technology was developed, the shares of the intellectual property rights were allocated in proportion to the amount of funding and background technology provided by each participant (Perry, 2001).

This short account of US strategies to promote the development of unconventional natural gas, including CBM, reveals three key success factors. First, the federal government acted with a major coordinated push from the very beginning, led by the legislature and four key agencies: the Department of Treasury, the FERC, the Department of Energy and the USGS. Second, the tax credit provided a very significant economic stimulus for unconventional gas production. Third, and most important in the context of this analysis, was the creation of the Gas Research Institute to manage and coordinate R\&D projects to ensure economic benefit. In this way, many diverse actors across the highly competitive US oil and gas industry were brought together to address the challenge of unconventional gas development. As will described in the next section, the prevailing conditions and strategies deployed in China were quite different.

\section{China's national system of innovation and its application to coal-bed methane}

5.1 China's national system of innovation

China's NSI has evolved significantly since the 1950s when the Soviet Union played a significant role in the overall design of the economy, including the systems and structures for R\&D. As with the wider economy, R\&D was centrally planned with a focus on the military and on heavy industry, but implementation was fragmented. The gradual marketisation of the economy in the 1980s was accompanied by a sustained growth in expenditure on $R \& D$ by both government and enterprises, and by a degree of decentralisation of decision-making on R\&D (Liu and White, 2001; Gu and Lundvall, 2006).

During the 1980s and 1990s the government launched several strategic research programmes aimed variously at selected industries, universities, state laboratories and science parks. The growing R\&D activity resulted in a rise in the number of patents filed by manufacturers, though primarily for design rather than utility or invention (Liu and White, 2001) and in the number of publications in international academic journals by university staff (Zhang et al., 2013). Among enterprises, state-owned enterprises (SOEs) were generally less innovative. They invested proportionately less in R\&D than non-SOEs, and small and medium-sized enterprises were more innovative than larger companies (Huang, 2010).

At this stage, the level of diffusion of ideas and technologies in China's NSI remained low for a number of institutional reasons. The SOEs were slow to develop links with universities 
JSTPM 14,3

and government research institutes, and local clusters and networks were weak (Liu and White, 2001; Gu and Lundvall, 2006). Organisations were reluctant to cooperate in innovation as the legal framework for IPR was still weak (Liu and White, 2001). The gap between the research of government research institutes and industry requirements, inherited from the earlier Soviet approach, persisted (Liu, 2009). Moreover, the downstream integration of universities and government research institutes further constrained the flow of technologies to manufacturers through sale or licensing (Liu and White, 2001).

In response, the government progressively established specialised units in government research institutes to make links with industry in selected sectors, including energy, and set up high technology incubation centres and local technology markets. Together these measures succeeded in raising the level of diffusion (Liu and White, 2001; Hu and Matthews, 2008). However, the influence of the central government over science and technology policy remained strong, though was steadily declining (Chen and Naughton, 2016).

Since the early 2000s, China's Government has placed progressively greater emphasis on domestic R\&D and indigenous innovation. As a result, sales of domestic technology has outstripped that of foreign technology (Gu and Lundvall, 2006; Chen and Naughton, 2016). This success has involved a central role for the government in supporting R\&D as, variously, a strategic investor, a business partner, a customer and a supervisor (Bazavan, 2019).

Since 2014, the government has reinforced its support for R\&D by making innovation a key component of the national development strategy. Key documents included the 13th Five-Year Plan for Science and Technology 2016-2020 and Made in China 2025. To support these aspirations, the government has increased its role in managing science and technology (Cao et al., 2018). It has provided clear focus areas for $R \& D$ and taken steps to improve coordination across government and remove institutional and structural barriers to innovation (Cyranoski, 2014). The government has also rationalised the numerous funding programmes into five categories and outsourced the management of these programmes to professional agencies. The Ministry of Science and Technology remains central to R\&D policy-making, leading the inter-ministerial deliberations that set the strategic R\&D agenda. The National Natural Science Foundation was removed from the purview of the State Council, and now lies under the Ministry of Science and Technology. More rigorous procedures have been introduced to evaluate projects through domestic and international peer review and in terms of their impact.

Despite the efforts put into these reforms, many assessments of their impacts have been unfavourable. The approach is seen as excessively top-down and supply-side, rather than demand-side (Wang and Li, 2019). The efficiency of innovation remains low; in other words, the ratio of resource deployed versus innovative results achieved is low, though is improving (Qiu, 2020). The role of scientists in setting the government's research agenda and managing research programmes appears to have declined (Zhi and Pearson, 2017). Government strategy appears to emphasise low risk, applied research with short-term commercial deliverables (Zhi et al., 2013). R\&D collaboration has remained weak, as have technology adoption and diffusion. The education system is seen as still being inappropriate to spur creativity and multi-disciplinary R\&D, despite the rhetoric in support of innovation and the IPR framework requires further enhancement (Wang and Li, 2019).

The industrial focus of these R\&D efforts resulted in a large share of funding flowing to enterprises, with a greater proportion allocated to SOEs as they were still perceived as vital actors in the economy. Studies to evaluate the innovation performance of SOEs over the period 20002015 revealed that SOEs continued to less innovative than non-SOEs in terms of patents and innovative products for a given input of R\&D finance (Zhou et al., 2017; Kroll and Kou, 2019). Nevertheless, specific categories of SOEs showed a higher level of innovation than others, notably: those in which the state held a minority rather than a majority share; those operated in 
more competitive markets; those that were founded as start-ups; and those in high-tech industries and those directly facing the market (Cao et al., 2016; Zhou et al., 2017).

Some of these weaknesses in the NSI can be seen in the SSI for CBM, notably preferential funding for SOEs, inadequate financing of basic research and weak coordination (Section 5.3).

\subsection{Key features of China's oil and gas industry}

Unlike the diverse and competitive situation in the USA, China's oil and gas industry is dominated by three wholly state-owned national oil companies (NOCs) and their listed subsidiaries: CNPC and PetroChina Ltd, Sinopec Group and Sinopec Ltd and CNOOC and CNOOC Ltd. The listed subsidiaries have long held the resource rights to most of the country's onshore oil and gas resources. However, it was the Ministry of Coal Industries that first took an interest in CBM. To address resource rights and to promote the exploitation of CBM, the government created the China United Coalbed Methane Corporation (CUCBM) in 1996, giving it a monopoly over all CBM resources. The two shareholders were CNPC (later PetroChina) and the China National Coal Corporation ("China Coal"). Little progress was made in developing the CBM resource. PetroChina had little interest in CBM as it was directing its funds towards other sources of gas, and China Coal lacked expertise in exploration drilling as well as the funds, and was focusing its efforts on coal mining. Meanwhile the Ministry of Land and Resources was carrying out some exploratory drilling in coal mining areas, and the Jincheng Anthracite Mining Group ran some pilot CBM development projects (Regan and Zhu, 2014)

In 2007, the government removed CUCBM's monopoly on foreign cooperation. A year later PetroChina withdrew from CUCBM and became a CBM player in its own right. Sinopec and a small number of other local state-owned Chinese enterprises also began to explore for CBM. In 2010, CNOOC Ltd bought a 50\% stake in CUCBM and upped its stake to $70 \%$ in 2013 (Regan and Zhu, 2014).

The first foreign companies to explore for CBM in China during the 1990s were USA majors such as Chevron, ConocoPhillips, Arco (later BP) and Texaco. A combination of poor flow rates, low demand for gas and low gas prices resulted in these large companies moving out and passing the opportunity to smaller foreign players in the early 2000s. The most active of these have been Green Dragon, Sino Gas and Energy and Far East Energy. One major oil company, Shell, took out a PSC for CBM in 2007. Other foreign companies included Dart Energy (previously Arrow), Asia American Gas and Pacific Asia Petroleum (Beveridge and Chan, 2010). Until recently, foreign companies were obliged to operate under production sharing contracts (PSCs) in partnership with Chinese state-owned resource right holders, notably CUCBM and PetroChina. Whilst a few foreign companies succeeded in producing small quantities of CBM, the structure of the standard Chinese PSC was quite unsuited to the nature of CBM development (Regan and Zhu, 2014). As a result, CUCBM and PetroChina continued to dominate the CBM industry and held most of the CBM production and exploration licenses. Two other SOEs, CNOOC and Sinopec played a much smaller role. In 2016, these four SOEs held 64 out of the 104 CBM exploration licenses. The other 40 licenses were held by 24 local enterprises across 14 provinces, many of which were not highly prospective [3].

As mentioned above (Section 2), the government has recently taken two steps to increase the number and diversity of actors involved in the development of CBM (Jin et al., 2019). In 2017, it delegated authority for granting CBM resource rights to six provincial governments on a trial basis: Shanxi, Fujian, Jiangxi, Hubei, Guizhou and Xinjiang. This resulted in an increase in the number of CBM exploration licenses in operation from 104 in 2016 to 121 in 2020. More importantly, the number of non-SOE license holders increased from 24 to 36. Twenty of these were new actors, 9 enterprises having withdrawn from CBM exploration. 
JSTPM 14,3

The total number exploration licences held by non-SOEs rose from 40 to 68 . Over the same period the share of these licenses held by the SOEs declined from $62 \%$ in 2016 to $44 \%$ in 2019. Of the 6 regions which had been granted licensing rights, only Shanxi and Guizhou saw an increase in the number of active exploration licenses, from 3 to 21 in Shanxi and from 7 to 19 in Guizhou. These are both coal-rich provinces, and Shanxi is the source of most of China's CBM production today. The other four provinces showed no increase in license numbers [4].

While the increased number of companies active in exploration is to be welcomed, it is too early to judge whether this will help accelerate technological innovation and the production of CBM. Many of the new actors will likely face steep learning curves, as CBM development is quite unlike that for other forms of unconventional gas such as shale gas. Also, the resource quality in many of these new license areas may not be high and the area of each block is seen as being too small (Wood Mackenzie, 2019; Xu, 2021).

In a second move, in 2019, the government removed the requirement for foreign enterprises to operate under a PSC or in joint venture with a Chinese company. While a few small independent companies continue to operate, the majors such as Chevron, Shell and BP have withdrawn from $\mathrm{CBM}$, and no new foreign investors had taken up the opportunity offered by the relaxation of rules on foreign investment as of May 2021 [5].

\subsection{China's sectoral system for innovation as it relates to coal-bed methane}

As mentioned in Section 2, the government is estimated to have directed billions of dollars towards R\&D in support of coalbed methane development since the beginning of the century. However, insufficient amounts have been directed at basic research. Rather the majority of the funds were spent on technological development and pilot projects (Wu, 2012; Tao et al., 2019a). Moreover, our own incomplete collation from available primary online Chinese sources indicates that a substantial share of government R\&D funds for CBM has been granted to a relatively small number of enterprises, research institutes and university laboratories. The major recipients were the NOCs and their research institutes, and to CUCBM, as these enterprises were expected to play a leading role in the CBM industry. Thus earlier observations of the central role played by SOEs in industrial research in China's energy sector (Karplus, 2007; Anadon, 2012) appear to be valid today, at least for CBM. The China University of Geosciences and Chongqing University received a disproportionate share of the funding to universities [6].

A further deficiency has been the apparent lack of effective mechanisms for coordinating CBM R\&D. In 2006, the NDRC approved the establishment of a National Engineering Research Center for the Development and Utilization of Coalbed Methane. The founding shareholders were CUCBM, PetroChina, Sinopec, Huaibei Mining, Beijing Orion Energy and the China University of Geosciences in Beijing [7]. However, this organisation does not have the capacity or authority to play a national coordinating role [8].

In 2009, 14 enterprises, universities and research institutes created the CBM Industry Technological Innovation Strategic Alliance [9]. Membership grew to 41 by 2019 [10]. While the formal aims of the Alliance included promoting collaboration, disseminating findings and promoting the adoption of technologies [11], interviews with the secretariat and with academic researchers in Beijing indicated that the organisation functioned very informally, unlike the US Gas Research Institute. It did not fund research, neither did it actively build collaborative partnerships [12]. These observations support Anadon's (2012) contention that links between basic and applied research and between SOEs and private enterprises remain weak in China's energy sector. Further, there is no evidence that the government has created new organisations to promote and coordinate innovation in the oil and gas industry, let alone for CBM. 
In summary, the relative lack of success of technological innovation in China's CBM industry can be attributed, in part at least, to the preferential directing of R\&D funds to SOEs and a limited number of universities for applied research, at the expense of basic research. This has been exacerbated by the historically small number of actors involved in $\mathrm{CBM}$ development and the high barriers to entry. In addition, the systems for research collaboration and the diffusion of results continue to be weak in both the NSI and the SSI. These features are in sharp contrast to the context of innovation in support of CBM development in the USA and go some way to explaining the different outcomes. During the eleven years after annual output reached $1.0 \mathrm{bcm}$, China's production reached $6.0 \mathrm{bcm}$ while that of the USA reached $35.1 \mathrm{bcm}$ (Figure 1).

\section{Conclusions}

One of the reasons why China's efforts to exploit its CBM resources have not met with success similar to that of the USA is the greater geological complexity and specific characteristics of the resource in China. Nevertheless, more than 20 years of R\&D and increasing levels of state funding have failed to lead to a significant technological breakthrough. As a result, annual CBM production in China has been rising only slowly and has yet to show any sudden acceleration as occurred in the USA in 1989 (Figure 1). One of the underlying reasons for this difference is the contrast between the rapid and coordinated effort that the US Government put in during the late 1970s to support unconventional gas development and the much slower roll out of supporting policies in China.

However, the slow progress of CBM development in China is also due to the way in which R\&D has been organised at both national and sectoral levels. Innovation studies have shown that sustained innovative success requires certain features to be present at national and sectoral levels. Of particular importance are collaboration of different types of actors in the R\&D activities, effective mechanisms for diffusing R\&D outputs and a diversity of actors. The inadequate level of innovation in China's CBM industry can be attributed, at least in part, to the low level of R\&D collaboration within the country's oil and gas industry and the weak diffusion of R\&D findings. This feature of the SSI for CBM arises from the characters of the NSI and the national oil and gas industry, dominated as it is by SOEs. This stands in sharp contrast to the diverse and competitive nature of the US oil and gas industry, and the strong role of collaboration in its SSI for CBM that reflects that in the NSI.

The policy programme put in place by the US Government in the 1970s to encourage the exploitation and use of domestic natural gas resources revealed an almost simultaneous launch of multiple policy instruments by different agencies and the creation of an organisation, the Gas Research Institute, to fund, manage and coordinate gas research across the country. The leadership of the Gas Research Institute put in place rigorous procedures for project selection, management and termination and systems for dissemination of results. It also involved many diverse organisations including oil and gas companies, service companies, government research institutes and universities. These efforts were reinforced by the large number and diversity of commercial actors involved in CBM development, and by the long history of collaboration between companies and universities.

In contrast, China's efforts to support CBM R\&D have grown in a piecemeal fashion and have been less well coordinated. Moreover, research funding has tended to focus on a relatively small number of actors. R\&D collaboration and the diffusion of findings have not been particularly effective. These deficiencies in the CBM SSI reflected features of the wider NSI as well as of the nature of its oil and gas industry. China's NSI continues to be characterised by top-down management that has recently been reinforced, a focus on applied research with short-term outcomes, a concomitant underfunding of basic research, and weak connections between basic and 
JSTPM 14,3

applied research. Collaboration between organisations is constrained by, among other factors, the inadequate IPR framework and inward-looking attitudes in larger organisations such SOEs.

The SSI for CBM R\&D lies within the oil and gas industry which is dominated by a small number of large SOEs. The innovation efficiency of China's SOEs generally is less impressive than privately-owned enterprises, but the latter play only a marginal role in the production of natural gas. State R\&D funding for CBM has been directed at a limited number of actors, mainly the research institutes of the SOEs and a small selection of universities. Basic research has been underfunded, and no effective mechanisms appear to have been put in place to coordinate research, build collaboration and promote the diffusion and adoption of findings.

While this paper has focused on deficiencies in the systems for supporting CBM R\&D, it is evident as discussed earlier (Section 2), that there are other reasons for the slow development of this resource in China. Most notable is the weak economic incentive, notwithstanding the $0.03 \mathrm{RMB}$ per cubic meter subsidy for production and the $175 \%$ tax deduction. In the absence of much stronger economic incentives to exploit CBM, technological progress is likely to remain incremental unless the government substantially improves the systems for funding and managing R\&D in this field.

China's Government has long had a preference for maximising the domestic production of natural resources such as gas. Its growing dependence on natural gas imports and the desire to substitute gas for coal has accentuated the priority placed on energy security. This has likely been one factor behind the decision to allow an increasing number of enterprises to gain rights to CBM resources. To date, only Chinese enterprises have taken advantage of this opportunity, and most are local state-owned enterprises. Few of them are will have substantial R\&D capacity. Unless they are able to collaborate with the incumbent corporate and research actors, they are unlikely to be successful in their quest for CBM production unless they encounter very favourable geological conditions. Thus, the need is now even greater than before for an organisation like the US Gas Research Institute to coordinate the funding and management of R\&D to maximise collaborative efforts to boost China's CBM production. The same argument applies to other unconventional oil and gas resources such as shale gas and tight oil.

The weak innovation to support CBM development is certainly not typical for China's industrial innovation. The level of innovation seems to depend greatly on the structure and ownership of the industry in question. Those industries dominated by SOEs tend to be less innovative than those with an active private sector, even if state enterprises are also present in the sector (Tse, 2020). The example of fifth-generation mobile technology shows that state-backed technological development can be effective in China (Triolo, 2020), but, of course, the strategic economic benefits for this technology are likely to be much greater than those to be derived from CBM.

\section{Notes}

1. Website of the American Petroleum Institute, www.api.org/membership/members (accessed 24 April 2021).

2. Website of the Independent Petroleum Association of America, www.ipaa.org/independentproducers/ (accessed 24 April 2021).

3. Data from the website of the Ministry Natural Resources, http://kyqgs.mnr.gov.cn/index.jhtml (accessed 25 May 2021).

4. Data from the website of the Ministry Natural Resources, http://kyqgs.mnr.gov.cn/index.jhtml (accessed 25 May 2021).

5. Xu Yihe, Upstream, Beijing, personal communication, 25 May 2021; Xiong Jin, King \& Wood Mallesons, Beijing, personal communication, 25 May 2021. 
6. See websites of 863 and 973 programmes, National Science and Technology major project "Development of large oil and gas fields and CBM", National Key R\&D Programmes, National Science and Technology major projects, and National Natural Science Foundation.

7. See website of the National Energy Adminstration www.nea.gov.cn/2007-10/12/c_131110086.htm (accessed 12 November 2019).

8. Interviews in Beijing, September 2019.

9. See website of National Science and Technology Major Projects, www.nmp.gov.cn/gzxgz/yqtmc/ 201003/t20100309_2058.htm (accessed 19 November 2019).

10. See website of the China Industry Technology Innovation Strategic Alliance, www.citisa.org/ lianmenghuodong/2829.html (accessed 17 August 2019).

11. See website of the China Industry Technology Innovation Strategic Alliance, www.citisa.org/ gongzuotansuo/2010niandugechuangxinzhanluelianmenggongzuozongjie/581.html (accessed 17 August 2019).

12. Interviews in Beijing, September 2019.

\section{References}

Anadon, L.A. (2012), "Missions-oriented RD\&D institutions in energy between 2000 and 2010: a comparative analysis of China, the United Kingdom, and the United States", Research Policy, Vol. 41, pp. 1742-1756.

Andrews-Speed, P. and Yao, L. (2019), "The reform and regulation of china's oil and gas pipeline network", Oil, Gas and Energy Law Intelligence, Vol. 17 No. 5, p. 8.

Anonymous (2021), "DOE's unconventional gas research programs 1976-1995. MRCP program design and overview", available at: www.geographic.org/unconventional_gas_research/ mrcp_program.html (accessed 2 May 2019).

Bazavan, A. (2019), "Chinese government's shifting role in the national innovation system", Technology Forecasting and Social Change, Vol. 148, Article 119738.

Beveridge, N. and Chan, A. (2010), "Coal bed methane: is it time for China's unconventional gas revolution?”, Bernstein Asia-Pac Energy, Bernstein Research, Hong Kong.

British Petroleum (1958), Our Industry, 3rd ed., The British Petroleum Company, London.

Burnett, W.M., Monetta, D.J. and Silverman, B.G. (1993), "How the gas research institute (GRI) helped transform the US natural gas industry", Interfaces, Vol. 23 No. 1, pp. 44-58.

Cao, X., Cumming, D.J., Zhou, S. and Zhou, L. (2016), "State ownership and corporate innovation efficiency”, Research Collection, Lee Kong Chian School of Business, Singapore Management University, Singapore, November.

Cao, C., Li, N. and Liu, L. (2018), "Reform of China's science and technology system in the Xi Jinping era”, China: An International Journal, Vol. 16 No. 3, pp. 120-141.

Carlsson, B. and Stankiewicz, R. (1991), "On the nature, function and composition of technological systems”, Journal of Evolutionary Economics, Vol. 1 No. 2, pp. 93-118.

Chen, L. and Naughton, B. (2016), “An institutionalized policy-making mechanism: China's return to techno-industrial policy”, Research Policy, Vol. 45 No. 10, pp. 2138-2152.

Cyranoski, D. (2014), "Chinese science gets mass transformation. Teamwork at Centre for Chinese academy of sciences reform", Nature, Vol. 513 No. 7519, pp. 468-469.

Edquist, C. (2001), "The systems of innovation approach and innovation policy: an account of the state of the art", paper presented at DRUID Conference, 12-15 June 2001, Aalborg, available at: www. researchgate.net/publication/228823918_The_Systems_of_Innovation_Approach_and_Innovation_ Policy_An_Account_of_the_State_of_the_Art/references (accessed 3 November 2019). 
JSTPM 14,3

Flaim, T. (1979), "The structure of the US petroleum industry: joint activities and affiliations", The Antitrust Bulletin, Vol. 24 No. 3, pp. 555-572.

Fryklund, B., Smith, C. and Flanagan, B. (2019), The Economic Contribution of Independent Operators in the United States, IHS Markit.

Gas Research Institute (1987), Historical Review of Gas Research Institute Research and Development, Gas Research Institute, Chicago, IL.

Gesling, L. (1992), "Innovation and the development of industrial networks", in Lundvall, B.-A. (Ed.), National Systems of Innovation. Toward a Theory of Innovation and Interactive Learning, Anthem Press, London, pp. 119-132.

$\mathrm{Gu}, \mathrm{S}$. and Lundvall, B.A. (2006), "China's innovation system and the move towards harmonious growth and endogenous innovation", Innovation, Vol. 18 No. 4, pp. 413-440.

Hu, M.C. and Matthews, J.A. (2008), "China's national innovation capacity”, Research Policy, Vol. 37 No. 9, pp. 1465-1479.

Huang, K.G. (2010), “China’s innovation landscape”, Science, Vol. 329 No. 5992, pp. 632-633.

Intarakumnerd, P. and Goto, A. (2018), "Role of public policy research institutes in national innovation systems in industrialized countries: the cases of Fraunhofer, NIST, CSIRO, AIST and ITRI", Research Policy, Vol. 47 No. 7, pp. 1309-1320.

Jin, X., Ai, L. and Li, S. (2019), "Foreign investment in China CBM industry - restrictions removed", available at: www.chinalawinsight.com/2019/07/articles/foreign-investment/foreign-investmentin-china-cbm-industry-restrictions-removed/

Jones, R.O., Mead, W.J. and Sorenesen, P.E. (1978), "Free entry into crude oil and gas production and competition in the US oil industry", Natural Resources Journal, Vol. 18 No. 4, pp. 859-875.

Karplus, V. (2007), "Innovation in China's energy sector", Working paper No. 61, Program on Energy and Sustainable Development, Stanford University.

Kennedy, S. (2020), “Touching the elephant: explaining patterns of China's innovation”, in Kennedy, S. (Ed.), China's Uneven High-Tech Drive. Implications for the United States, China Innovation Policy Series, Center for Strategic and International Studies, Washington, DC DC, February, pp. 1-7.

Kroll, H. and Kou, K. (2019), “Innovation output and state ownership: empirical evidence form China's listed firms", Industry and Innovation, Vol. 26 No. 2, pp. 176-198.

Li, H., Lau, H.C. and Huang, S. (2018), "China's coalbed methane development: a review of the challenges and opportunities in subsurface and surface engineering", Journal of Petroleum Science and Engineering, Vol. 166, pp. 621-635.

Liu, X. (2009), "National innovation systems in developing countries: the Chinese national innovation system in transition", in Lundvall, B.A., Joseph, K.J., Chaminade, C. and Vang, J. (Eds), Handbook of Innovation Systems and Developing Countries, Edward Elgar, Cheltenham, pp. 119-139.

Liu, X. and White, S. (2001), “Comparing innovation systems: a framework and application to China's transitional context", Research Policy, Vol. 30 No. 7, pp. 1091-1114.

Liu, Z. and Sun, R. (2019), "Shanxi tightens coalbed methane mining oversight", China Daily, 15 February, available at: www.chinadaily.com.cn/a/201902/15/WS5c66293fa3106c65c34e98bf. html (accessed 12 November 2019).

Lundvall, B.-A. (1992), “Introduction”, in Lundvall, B.-A. (Ed.), National Systems of Innovation. Toward a Theory of Innovation and Interactive Learning, Anthem Press, London, pp. 1-19.

Lundvall, B.-A. (2007), "National innovation systems - analytical concept and development tool", Industry and Innovation, Vol. 14 No. 1, pp. 95-119.

Malerba, F. (2002), “Sectoral systems of innovation and production”, Research Policy, Vol. 31 No. 2, pp. 247-264.

Malerba, F. (2006), "Sectoral systems: how and why innovation differs across sectors", in Fagerberg, J. and Mowery, D.C. (Eds), The Oxford Handbook of Innovation, Oxford University Press, Oxford, pp. 380-406. 
Masterlerz, M. and Drobniak, A. (2020), "Coalbed methane: reserves, production, and future outlook”, in Letcher, T. (Ed.), Future Energy, 3rd ed., Elsevier, Amsterdam, pp. 97-109.

Melaas, A. and Zhang, F. (2016), National Innovation Systems in the United States and China. A Brief Review of the Literature, The Fletcher School, Tufts University, Medford, MA.

Mowery, D.C. (1998), "The changing structure of the US national innovation systems: implications for international conflict and cooperation in R\&D policy", Research Policy, Vol. 27 No. 6, pp. 639-654.

Mowery, D.C. and Rosenberg, N. (1993), "The US national innovation system”, in Nelson, R.R. (Ed.), National Innovation Systems. A Comparative Analysis, Oxford University Press, New York, NY, pp. 29-75.

Murray, D.K. (1996), "Coalbed methane in the USA: analogues for worldwide development", in Gayer, R. and Harris, I. (Eds), Coalbed Methane and Coal Geology, Geological Society Special Publication, No. 109, pp. 1-12.

National Academic of Sciences of the US (2001), "Evaluation of the fossil energy programs", Energy Research at DOE: Was it Worth it? Energy Efficiency and Fossil Energy Research 1978 to 2000, National Academy of Sciences of the US, available at: www.nap.edu/read/10165/chapter/6 (accessed 16 May 2019).

Nelson, R.R. (1992), "National innovation systems: a retrospective study", Industrial and Corporate Change, Vol. 1 No. 2, pp. 347-374.

Nelson, R.R. and Rosenberg, N. (1993), "Technical innovation and national systems”, in Nelson, R.R. (Ed.), National Innovation Systems. A Comparative Analysis, Oxford University Press, New York, NY, pp. 3-21.

Perry, K. (2001), "Summary of the GTI coalbed methane research program and review of related tight gas sands and Devonian shale programs", Unpublished report, Gas Technology Institute, Des Plaines, IL.

Popper, S.W. and Wagner, C.S. (2002), "New foundations for growth: the US innovation systems today and tomorrow", RAND Report MR-1338.0-OSTP, RAND Corporation, Arlington, VA.

Qiu, M. (2020), "The larger but not leaner fat tech dragon”, in Kennedy, S. (Ed.), China's Uneven HighTech Drive. Implications for the United States, China Innovation Policy Series, Center for Strategic and International Studies, Washington, DC, February, pp. 8-11.

Regan, T. and Zhu, C. (2014), "Twenty five years of coal bed methane development in China", The Journal of World Energy Law and Business, Vol. 7 No. 5, pp. 423-447.

Simons, K.L. and Walls, J.L. (2010), “The US national innovation system”, in Narayanan, V.K. and O'Connor, G.C. (Eds), Encyclopedia of Technology and Innovation, Wiley-Blackwell, Malden, MA.

Smith, K. (1997), "Economic infrastructures and innovation systems", in Edquist, E. (Ed.), Systems of Innovation. Technologies, Institutions and Organizations, Pinter, London, pp. 86-106.

Soot, P.M. (1991), "Tax incentives spur development of coalbed methane”, Oil and Gas Journal, 10 June, available at: www.ogj.com/articles/print/volume-89/issue-23/in-this-issue/production/tax-incentivesspur-development-of-coalbed-methane.html (accessed 24 April 2019).

State Council (2017), "Reform scheme for the transfer of mining rights", 16 June 2016, available at: www.mnr.gov.cn/dt/ywbb/201810/t20181030_2287039.html (accessed 29 March 2020).

Sun, M. and Huang, S. (1996), "Suggested policies to encourage coaled methane development in China", Natural Resources Forum, Vol. 20 No. 1, pp. 49-57.

Tao, S., Chen, S. and Pan, Z. (2019a), "Current status, challenges, and policy suggestions for coalbed methane industry development in China: a review", Energy Science and Engineering, Vol. 7 No. 4, pp. 1059-1074.

Tao, S., Pan, Z., Tang, S. and Chen, S. (2019b), "Current status and geological conditions for the applicability of CBM drilling technologies in China", International Journal of Coal Geology, Vol. 202, pp. 95-108. 
JSTPM 14,3

Triolo, P. (2020), "China's 5G strategy: be first out of the gate and ready to innovate", in Kennedy, S. (Ed.), China's Uneven High-Tech Drive. Implications for the United States, China Innovation Policy Series, Center for Strategic and International Studies, Washington, DC, February, pp. 21-28.

Tse, E. (2020), “China's systematic advantages for tech-enabled solutions”, in Kennedy, S. (Ed.), China's Uneven High-Tech Drive. Implications for the United States, China Innovation Policy Series, Center for Strategic and International Studies, Washington, DC, February, pp. 12-15.

US Energy Information Administration (undated a), "Coalbed methane production”, available at: www.eia. gov/dnav/ng/ng_prod_coalbed_s1_a.htm (accessed 20 October 2019).

US Energy Information Administration (undated b), "Natural gas policy act of 1978”, available at: www.eia. gov/oil_gas/natural_gas/analysis_publications/ngmajorleg/ngact1978.html (accessed 11 May 2019).

US Environmental Protection Agency (2010), "Coalbed methane extraction: detailed study report", Report number EPA-820-R-10-022, Environmental Protection Agency, Washington, DC.

US Geological Survey (2021), “Coalbed gas”, available at: https://energy.usgs.gov/OilGas/ UnconventionalOilGas/CoalbedGas.aspx (accessed 13 May 2019).

Wang, P. and Li, F. (2019), "China's organization and governance of innovation - a policy foresight perspective", Technological Forecasting and Social Change, Vol. 146, pp. 304-319.

Wood Mackenzie (2019), "China's gas production to double to 325 BCM in 2040", 28 August, available at: www.woodmac.com/press-releases/chinas-gas-production-to-double-to-325-bcm-in-2040/ (accessed 23 April 2021).

Wu, J. (2012), "Situation of unconventional natural gas exploration and development", Presentation September, available at: https://wenku.baidu.com/view/4ed479d3b9d528ea81c779f2.html?from= search (accessed 21 August 2019).

Xu, Y. (2021), "Coalbed methane targets always out of reach for China”, Upstream, 21 January 2021, available at: www.upstreamonline.com/production/coalbed-methane-targets-always-out-ofreach-for-china/2-1-941998 (accessed 15 May 2021).

Zhang, H., Patton, D. and Kenney, M. (2013), "Building global-class universities: assessing the impact of the 985 project”, Research Policy, Vol. 42 No. 3, pp. 765-775.

Zhi, Q. and Pearson, M. (2017), "China's hybrid adaptive bureaucracy: the case of the 863 program for science and technology", Governance, Vol. 30 No. 3, pp. 407-424.

Zhi, Q., Su, J., Ru, P. and Anadon, L.D. (2013), "The evolution of China's national energy R\&D programs: the role of scientists in science and technology decision making", Energy Policy, Vol. 61, pp. 1568-1585.

Zhou, K.Z., Gao, G.Y. and Zhao, H. (2017), "State ownership and firm innovation in China: an integrated view of institutional and efficiency logics", Administrative Science Quarterly, Vol. 62 No. 2, pp. 375-404.

\section{Further reading}

US Energy Information Administration (2021a), “Coalbed methane production”, available at: www.eia. gov/dnav/ng/ng_prod_coalbed_s1_a.htm (accessed 12 May 2021).

\section{Corresponding author}

Philip Andrews-Speed can be contacted at: cpandrewsspeed@hotmail.com

For instructions on how to order reprints of this article, please visit our website:

www.emeraldgrouppublishing.com/licensing/reprints.htm

Or contact us for further details: permissions@emeraldinsight.com 